and held that professorship with great distinction until his retirement in 1934 .

In his early investigative work McClure inclined to neurology, and he published work on the brain of primitive vertebrates and on the structure of nerve cells in molluses. His association with Prof. G. S. Huntington, however, led his interests into the field of the morphology and the functional anatomy of blood vessels and the lymphatic system. The collaboration led to classic accounts of the development of the mammalian inferior vena cava, accounts which really deserve the adjective exhaustive. The work with Huntington also resulted in a large number of publications on the early differentiation of lymphatic vessels. These contributions, in which it was insisted that lymphatic vessels can differentiate in situ from the embryonic mesenchyme, represented one side of a controversy that shook American anatomy during a period of years, for Dr. Florence Sabin's point of view, that lymph vessels arose only by centrifugal extension of endothelium from veins, was strongly supported by the powerful Johns Hopkins group of investigators. Strangely, the polemics on this problem were almost completely restricted to workers in the United States, possibly because of the preoccupation of European anatomists during the First World War. It was, however, a rewarding controversy, out of which much knowledge and some new techniques emerged.

McClure had been president of the American Association of Anatomists and for many years was a member of the Anatomical Society of Great Britain and Ireland. His distinction in his chosen field of work was such that he was included in the Cattell group of the leading thousand students of science of the United States as early as 1906.

$$
\text { J. D. BOyD }
$$

\section{Prof. C. T. Brues}

Charles Thomas Brows was born in West Virginia in 1879, took his first degree at the University of Texas, and briefly held appointments at Columbia, with the U.S. Department of Agriculture, and at the Milwaukee Public Museum. At the age of thirty, he went to Harvard as instructor in entomology under Wheeler, and he spent the remainder of his working life there. To be an entomologist in 1909 meant to be a systematist; and Brues was soon a recognized authority on several families of Hymenoptera and Diptera. During this phase he published his catalogue of African Braconidae, the volume on Phoridae in the Genera Insectorum and, with A. L. Melander, the first edition of their well-known "Key to the Families of North American Insects". But Brues was also a naturalist and his interests gradually developed along two principal lines: the fauna of hot springs, and the correlation of systematic affinities with food habits. Food selection by insects increasingly occupied his attention. $\mathrm{He}_{\mathrm{o}}$ wrote several important papers about it, interesting and valuable both to economic and academic entomologists; and finally, in 1946, summarized the whole field in his useful book, "Insect Dietary".

As a teacher of graduate students at the Bussey Institution, Brues was characterized by his helpfulness. His room was always open and he seemed cheerfully ready to put aside his own work and to lend himself, his mind, hands, time and tools, to his students. He was skilful in many small crafts and his skill was there to be called upon. In conversation and at symposia he rarely criticized, but was ready with useful suggestions. This willing disposition led Brues to undertake much extra work. Single-handed he edited thirty-six annual volumes of the entomological journal Psyche, and he served on innumerable boards and committees.

Brues was a man who helped where help was needed without counting the cost to himself or looking for any return. His former pupils and colleagues in many parts of the world will hear with regret that he died on July 29 in his seventy-seventh year, and will think of him with gratitude and affection.

GeORge Sati

\section{Dr. S. G. P. Plant}

Dr. S. G. P. Plant, who was senior lecturer and demonstrator at the Dyson Perrins Laboratory and secretary to the Delegates of the Oxford University Museum, died at Oxford on September 10.

Sydney Glenn Preston Plant was born at Leicester in 1896. He was educated at Wyggeston Grammar School and, in 1915, went up to Oxford as a Scholar of St. John's College, where he read for the final honour school of chemistry. As a young graduate he worked first under Dr. N. V. Sidgwick and later, as a senior demy of Magdalen College, under Prof. W. H. Perkin. He became a lecturer and demon. strator at the Dyson Perrins Laboratory, and since 1928 he had also been secretary to the Delegates of the Oxford University Museum. He served on the Council of the Chemical Society and on its publication committee, and he contributed many papers to its journal. He had, for many years, been treasurer of the Ashmolean Natural History Society.

Dr. Plant's interest in indoles and carbazoles grew out of his early work with Perkin, and he and his pupils have contributed much to our knowledge of this field of heterocyclic chemistry. He published a long series of papers on the substitution and addition reactions of the indole nucleus and the determination of the position of substituents in indoles and carbazoles. It is worthy of note that he discovered some of the first-known covalent derivatives of the alkali metals, compounds of great interest to Sidgwick in his early work on the electronic theory of valency.

But it is, perhaps, as a lecturer and tutor that Plant will be best remembered. His great love of chemistry and his outstanding powers of lucid exposition have inspired, year after year, numbers of undergraduates; many of thern began their researches with him and are better chemists for the excellent training they received under his keen and kindly supervision. He found scope for his real flair for organization at the Museum, and there, too, his unfailing good judgment, his tolerance and his delightful sense of humour stood him in good stead. He was as adept at dealing with the gratuitous communications of the discoverers of perpetual motion as with the everyday business of the Museum. A quiet and kindly man, he was liked and respected by all who knew him; he will be long remembered in Oxford, particularly at the Dyson Perrins Laboratory to which he gave such devoted service.

He married, in 1924, Winifred, daughter of William Crawford of Leicester. $\mathrm{He}$ is survived by her and by their two daughters.

J. C. SмIтH

M. L. TOMIINSON 